\title{
Magnetic and microwave-absorbing properties of $\mathrm{SrAl}_{4} \mathrm{Fe}_{8} \mathrm{O}_{19}$ powders synthesized by coprecipitation and citric- combustion methods
}

\author{
H Y HE*, J F HUANG, L Y CAO, Z HE and Q SHEN \\ Key Laboratory of Auxiliary Chemistry \& Technology for Chemical Industry, Ministry of Education, \\ Shaanxi University of Science and Technology, Xi'an, Shaanxi 710021, China
}

MS received 12 September 2010; revised 16 January 2011

\begin{abstract}
Al-substituted $M$-type hexaferrite is a highly anisotropic ferromagnetic material. In the present study, the coprecipitation and the citric-combustion methods of synthesis for $\mathrm{SrAl}_{4} \mathrm{Fe}_{8} \mathrm{O}_{19}$ powders were explored and their microstructure, magnetic properties, and microwave absorptivity examined. X-ray diffraction (XRD), scanning electron microscopy (SEM), a vibrating sample magnetometer, and a vector network analyser were used to characterize the powders. The XRD analyses indicated that the pure $\mathrm{SrAl}_{4} \mathrm{Fe}_{8} \mathrm{O}_{19}$ powder was synthesized at $900^{\circ} \mathrm{C}$ and $1000^{\circ} \mathrm{C}$ for $3 \mathrm{~h}$ by coprecipitation, but only at $1000^{\circ} \mathrm{C}$ for the citric-combustion processes. The SEM analysis revealed that the coprecipitation process yielded a powder with a smaller particle size, near single-domain structure, uniform grain morphology, and smaller shape anisotropy than the citric-combustion process. The synthesis technique also significantly affected the magnetic properties and microwave-absorptivity. Conversely, calcining temperature and calcining time had less of an effect. The grain size was found to be a key factor affecting the property of the powder. The powders synthesized by coprecipitation method at calcining temperature of $900^{\circ} \mathrm{C}$ exhibited the largest magnetization, largest coercivity, and best microwave absorptivity.
\end{abstract}

Keywords. $\mathrm{SrAl}_{4} \mathrm{Fe}_{8} \mathrm{O}_{19}$; coprecipitation method; shape anisotropy; magnetic property; microwave absorption.

\section{Introduction}

$M$-type hexaferrites possess excellent magnetic properties, a relatively high magnetocrystalline anisotropic field, and plate-like morphology. This makes this type of ferrite very suitable for microwave materials and microwave absorption. Certain cation substitutions have been shown to further change the anisotropy such as the Al substituted Ba-hexaferrite powder and Sr-hexaferrite film prepared by Choi et al (2003) and Heczko et al (2000). When rate of Al-substitution reached 4 , the magnetocrystalline anisotropic field $\left(H_{\mathrm{k}}\right)$ of the ferrite reached a maximum value about three times higher than the pure one (Choi et al 2003). In addition, it is generally believed that the microwave response frequency $(\omega k)$ of the ferrite increases with increase in $H_{\mathrm{k}}\left(\omega k=\gamma H_{\mathrm{k}}\right.$, where $\gamma$ is gyromagnetic ratio). Thus, $\mathrm{SrAl}_{4} \mathrm{Fe}_{8} \mathrm{O}_{19}$ ferrite might be a promising high frequency microwave material and high frequency microwave absorber. However, wet chemical synthesis and microwave property

*Author for correspondence (hehy@ sust.edu.cn) of the Al-substituted $M$-type ferrite were rarely reported in literature.

The properties of the substituted hexaferrites are largely dependent on their characteristics such as anisotropy, crystallinity, particle size, and substitution rate. Many process routes have been devised for the preparation of hexaferrite powders with refined particle size, narrow particle-size distribution, minimal particle agglomeration, and high crystallinity, including the hydrothermal process (Komarneni et al 1998), the microemulsion technique (Pankov 1997), and the coprecipitation route (Kreisel et al 2001). In recent years, the sol-gel combustion process has been widely studied for the synthesis of this type of ferrite powders (Wang et al 1996; Han et al 2009; Sablea et al 2009; Chen et al 2010). Various chelating agents have been explored for the formation of homogenous, stable, and transparent sol solutions, and likewise, various reducing agents such as citric acid (Han et al 2009; Chen et al 2010), stearic acid (Wang et al 1996) glycine, and urea (Sablea et al 2009) have been studied to find out the one that supplies the requisite energy to initiate the exothermic reaction amongst oxidants. These studies are important since the synthesis route can affect the characteristics of the synthesized powders. In this study, a comparison was made of the formation, particle morphology, anisotropy, magnetic properties, and microwaveabsorptivities between Al-substituted Sr-hexaferrite powders 
synthesized by the coprecipitation method and by the citric sol-gel combustion method.

\section{Experimental}

\subsection{Coprecipitation}

Ferric nitrate ninhydrate, strontium chloride dihydrate, and aluminium chlorite hexahydrate were dissolved with stirring in distilled water, with the resulting molarities being $0.05 \mathrm{M}$ for $\mathrm{Sr}^{2+}, 0.20 \mathrm{M}$ for $\mathrm{Al}^{3+}$, and $0.40 \mathrm{M}$ for $\mathrm{Fe}^{3+}$. Then, a sodium hydroxide aqueous solution was slowly added dropwise into the solution at room temperature with constant stirring condition until $\mathrm{pH}=9-10$. When the coprecipitation was complete, the precipitate slurry was filtrated and washed with anhydrous ethanol until $\mathrm{pH} \sim 7$, and then dried at $100^{\circ} \mathrm{C}$ for $10 \mathrm{~h}$. After preheating the precursor at $300^{\circ} \mathrm{C}$ for $1 \mathrm{~h}$, the precursor was heated in a furnace at a rate of $25^{\circ} \mathrm{C} \cdot \mathrm{min}^{-1}$ and then calcined at $900^{\circ} \mathrm{C}$ or $1000^{\circ} \mathrm{C}$ for $3 \mathrm{~h}$. Cooling process was naturally performed in furnace.

\subsection{Citric-combustion}

The ferric nitrate ninhydrate, strontium chloride dihydrate, aluminium nitrate hexahydrate were dissolved in distilled water containing citric acid by stirring for $0.5 \mathrm{~h}$. The solution had molarities of $0.05 \mathrm{M}^{3}$ for $\mathrm{Sr}^{2+}, 0.20 \mathrm{M}$ for $\mathrm{Al}^{3+}$, and $0.40 \mathrm{M}$ for $\mathrm{Fe}^{3+}$. The molar ratio of metal cations to citric acid was $1: 1 \cdot 5$. The $\mathrm{pH}$ of the solution was adjusted by slowly adding aqueous ammonia with constant stirring until $\mathrm{pH}=7-8$. The solution was then dried at $80^{\circ} \mathrm{C}$ or $100^{\circ} \mathrm{C}$ for $24 \mathrm{~h}$. After drying, the samples were heated at a rate of $\sim 25^{\circ} \mathrm{C} \cdot \mathrm{min}^{-1}$, and the combustion took place at $\sim 250^{\circ} \mathrm{C}$. After maintaining a temperarture of $250-300^{\circ} \mathrm{C}$ for $1 \mathrm{~h}$, the precursor was heated in a furnace at the rate of $25^{\circ} \mathrm{C} \cdot \mathrm{min}^{-1}$ and calcined at $900^{\circ} \mathrm{C}$ and $1000^{\circ} \mathrm{C}$ for $3 \mathrm{~h}$ and $5 \mathrm{~h}$, respectively. Cooling process was naturally performed in furnace.

\subsection{Sample analysis}

DSC/TG patterns of dried citric gel were analysed using a simultaneous TG-DTA/DSC apparatus (TG-DTA/DSC, Model No. STA409PC, Netzsch, Germany) in a $\mathrm{N}_{2}$ atmosphere at a heating rate of $10^{\circ} \mathrm{C} / \mathrm{min}$. The phase of the synthesized ferrite powders was identified at room temperature using a X-ray diffractometer $\left(\mathrm{XRD}, \mathrm{CuK}_{\alpha 1}, \lambda=\right.$ 0.15406 nm, Model No. D/Max-2200PC, Rigaku, Japan). Scanning electron microscopy (SEM, Model No. JXM6700F, Japan) was used to analyse the particle morphology of the powder. The magnetic property was measured with a vibrating sample magnetometer (VSM, Model No. Versa Lab, Quantun Design, USA), and variation of the reflection loss in $(\mathrm{dB})$ versus frequency was investigated in the range

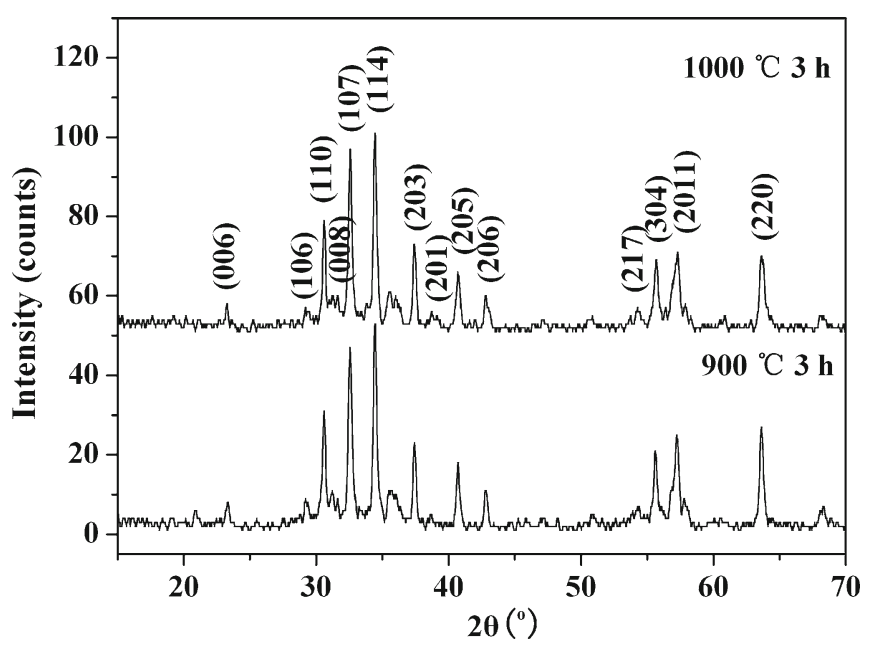

Figure 1. XRD patterns of $\mathrm{SrAl}_{4} \mathrm{Fe}_{8} \mathrm{O}_{19}$ powder synthesized by co-precipitation.

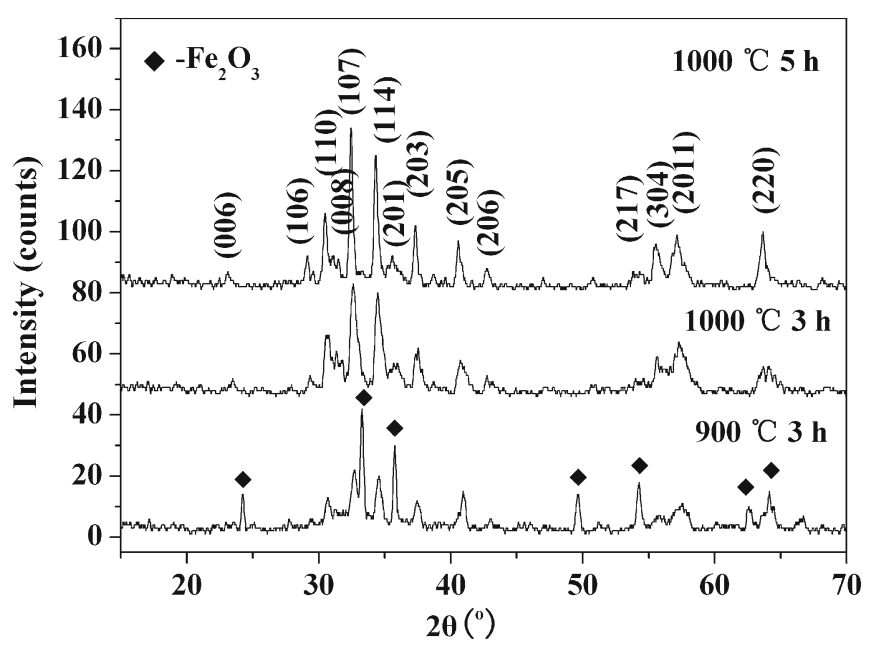

Figure 2. XRD patterns of $\mathrm{SrAl}_{4} \mathrm{Fe}_{8} \mathrm{O}_{19}$ powder synthesized by citric-combustion method.

of 10-20 GHz with a vector network analyser (Model No. N5230A, USA). For measuring reflection loss, the ferrites were mixed with an aqueous polyvinyl alcohol (20 wt $\%)$ and stirred for $1 \mathrm{~h}$. Specimens with a thickness of $1.5 \mathrm{~mm}$ were finally formed by cold isostatic pressing of $100 \mathrm{MPa}$.

\section{Results and discussion}

Figures 1 and 2 illustrate XRD patterns of the powders synthesized by coprecipitation and citric-combustion methods, respectively. The samples synthesized by coprecipitation all have a pure $\mathrm{SrAl}_{4} \mathrm{Fe}_{8} \mathrm{O}_{19}$ phase when the precursor was calcined at $900^{\circ} \mathrm{C}$ and $1000^{\circ} \mathrm{C}$. For the citric-combustion samples, the samples calcined at $1000^{\circ} \mathrm{C}$ for $3 \mathrm{~h}$ and $5 \mathrm{~h}$ were pure $\mathrm{SrAl}_{4} \mathrm{Fe}_{8} \mathrm{O}_{19}$ phase; the samples calcined at $900^{\circ} \mathrm{C}$ for 


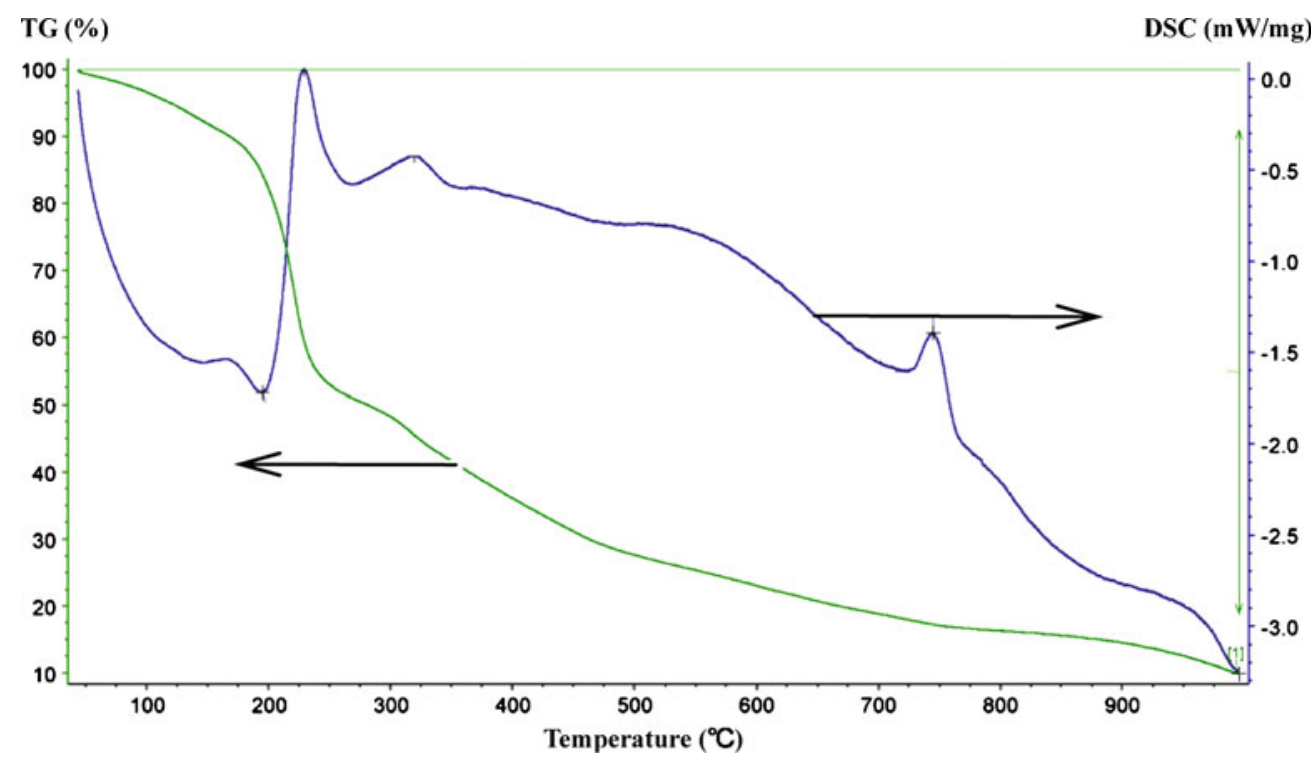

Figure 3. TG/DSC of citric acid gel containing metal cations.

$5 \mathrm{~h}$ were $\mathrm{Fe}_{2} \mathrm{O}_{3}$ phase. In this study, the pure $\mathrm{SrAl}_{4} \mathrm{Fe}_{8} \mathrm{O}_{19}$ phase was obtained at $1000^{\circ} \mathrm{C}$ for the longer time of $3 \mathrm{~h}$ compared to the $5 \mathrm{~h}$ reported in literature (Wang et al 1996; Han et al 2009). The TG/DSC curves of dried citric gel indicated that the gel still exhibited endothermic and agravic tendencies until $950^{\circ} \mathrm{C}$ (figure 3). This feature could have resulted from the decomposition of the $\mathrm{SrCO}_{3}$, which may be the reason why the citric-combustion synthesis route for $\mathrm{SrAl}_{4} \mathrm{Fe}_{8} \mathrm{O}_{19}$ required a higher calcining temperature.

The lattice constants of the powders were calculated using the $d, h, k$, and $l$ values of the strong (110), (008), (107), (114), (203), (2011), and (220) peaks in the XRD patterns according to the equation

$$
\frac{a^{2}}{d^{2}}=\frac{4}{3}\left(h^{2}+h k+k^{2}\right)+l^{2} \frac{a^{2}}{c^{2}} .
$$

The unit cell volume $\left(V_{\text {cell }}\right)$ of the hexagonal system was calculated as follows

$$
V_{\text {cell }}=0 \cdot 866 a^{2} c
$$

where the numeric factor is constant for the hexagonal system. As calculated, the lattice parameters $a, c, V_{\text {cell }}$ and $c / a$ ratio of the $\mathrm{SrAl}_{4} \mathrm{Fe}_{8} \mathrm{O}_{19}$ powders are listed in table 1. The $a, c$ and $V_{\text {cell }}$ value of the substituted ferrite powders were smaller than that of pure $\mathrm{SrFe}_{12} \mathrm{O}_{19}$ (PDF\#33-1340) while the $c / a$ ratios of the substituted ferrite powders were larger. These agree with the result reported by Choi et al (2003). The lattice parameter changes with the Al-substitution could be attributed to the smaller ionic radius of $\mathrm{Al}^{3+}(0.50 \AA)$ compared with $\mathrm{Fe}^{3+}(0 \cdot 64 \AA)$. Additionally, the $V_{\text {cell }}$ value decreased as calcining temperature increased for the coprecipitation-derived powders and as the calcining time increased for the sol-gel-derived powders. The lower calcining temperature for coprecipitation and longer calcining time for citric-combustion led to an increase of $c / a$ value.

In figure 4, the powder synthesized by coprecipitation had a smaller particle size near the single-domain, smaller shape anisotropy, and a more uniform plate-like morphology. With the increasing calcining temperature, the shape anisotropy

Table 1. Lattice parameter of $\mathrm{SrAl}_{4} \mathrm{Fe}_{8} \mathrm{O}_{19}$ powders determined from XRD data analysis, and

\begin{tabular}{|c|c|c|c|c|c|}
\hline \multirow[b]{2}{*}{ Sample } & \multicolumn{4}{|c|}{ Lattice parameter } & \multirow[b]{2}{*}{ Average grain size $(\mathrm{nm})$} \\
\hline & $a(\AA)$ & $c(\AA)$ & $c / a$ & $V_{\text {cell }}\left(\AA^{3}\right)$ & \\
\hline \multicolumn{6}{|l|}{ Coprecipitation method } \\
\hline $900^{\circ} \mathrm{C} 3 \mathrm{~h}$ & 5.8376 & $22 \cdot 9781$ & 3.9362 & $678 \cdot 1108$ & 55 \\
\hline $1000^{\circ} \mathrm{C} 3 \mathrm{~h}$ & $5 \cdot 8364$ & 22.9593 & 3.9339 & $677 \cdot 2775$ & 61 \\
\hline \multicolumn{6}{|l|}{ Citric-combustion method } \\
\hline $1000^{\circ} \mathrm{C} 3 \mathrm{~h}$ & 5.8469 & 22.9524 & 3.9255 & $679 \cdot 5123$ & 130 \\
\hline $1000^{\circ} \mathrm{C} 5 \mathrm{~h}$ & $5 \cdot 8515$ & $23 \cdot 0547$ & 3.9399 & 673.6153 & 165 \\
\hline $\mathrm{SrFe}_{12} \mathrm{O}_{19}(\mathrm{PDF} \# 33-1340)$ & $5 \cdot 887$ & $23 \cdot 037$ & 3.913 & 691.404 & \\
\hline
\end{tabular}
average grain size of the powders determined from SEM analysis. 

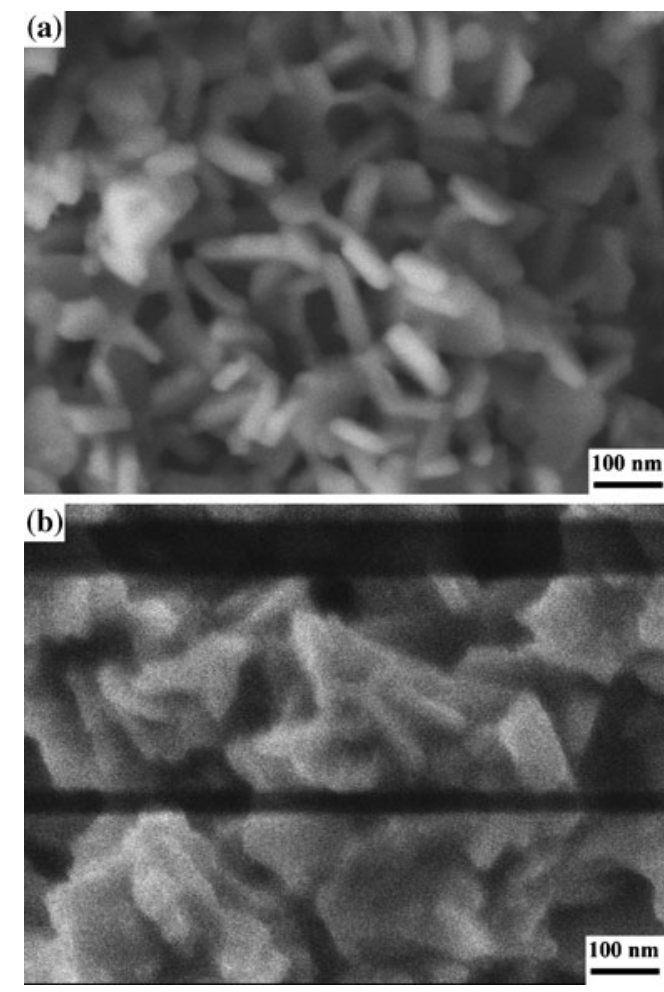

Figure 4. SEM micrographs of $\mathrm{SrAl}_{4} \mathrm{Fe}_{8} \mathrm{O}_{19}$ powders synthesized by co-precipitation method. The powders were calcined at (a) $900^{\circ} \mathrm{C}$ and (b) $1000^{\circ} \mathrm{C}$ for $3 \mathrm{~h}$.

and average grain size slightly increased. However, figure 5 indicates that the powder synthesized by citric-combustion had a larger particle size, a non-uniform plate-like morphology, and a larger shape anisotropy. As the calcining time increased though, the shape anisotropy decreased. The powder consisted of large grains up to $170-200 \mathrm{~nm}$ in size as well as small grains, and the average grain size appeared to increase with increasing calcining time.

Figure 6 shows the room temperature hysteresis loops of the powders synthesized by the coprecipitation method. The magnetization of the powders synthesized at $900^{\circ} \mathrm{C}$ and $1000^{\circ} \mathrm{C}$ were $30.50 \mathrm{emu} \cdot \mathrm{g}^{-1}$ and $28.49 \mathrm{emu} \cdot \mathrm{g}^{-1} \mathrm{respec}-$ tively. The easy axis of magnetization was parallel to the hexagonal $c$-axis and is described by the anisotropy constant $K_{1}$. Thus, a calcining temperature of $900^{\circ} \mathrm{C}$ could yield a more intense crystal growth in the $c$-axis than $1000^{\circ} \mathrm{C}$, which would result in the decrease in magnetization with increasing calcining temperature (figure 4). The coercivity was $9.07 \pm 0.04 \mathrm{kOe}$ and $8.51 \pm 0.04 \mathrm{kOe}$, respectively for the powders calcined at $900^{\circ} \mathrm{C}$ and $1000^{\circ} \mathrm{C}$. In general, magneto-crystalline anisotropy and grain size determine the possible coercivity, with maximum coercivity at the singledomain size. This could explain the slight decrease in coercivity with calcining temperature because of the increase in average grain size (table 1 ).

The powders synthesized by the citric-combustion method exhibited similar magnetic trends (figure 7). The magneti-
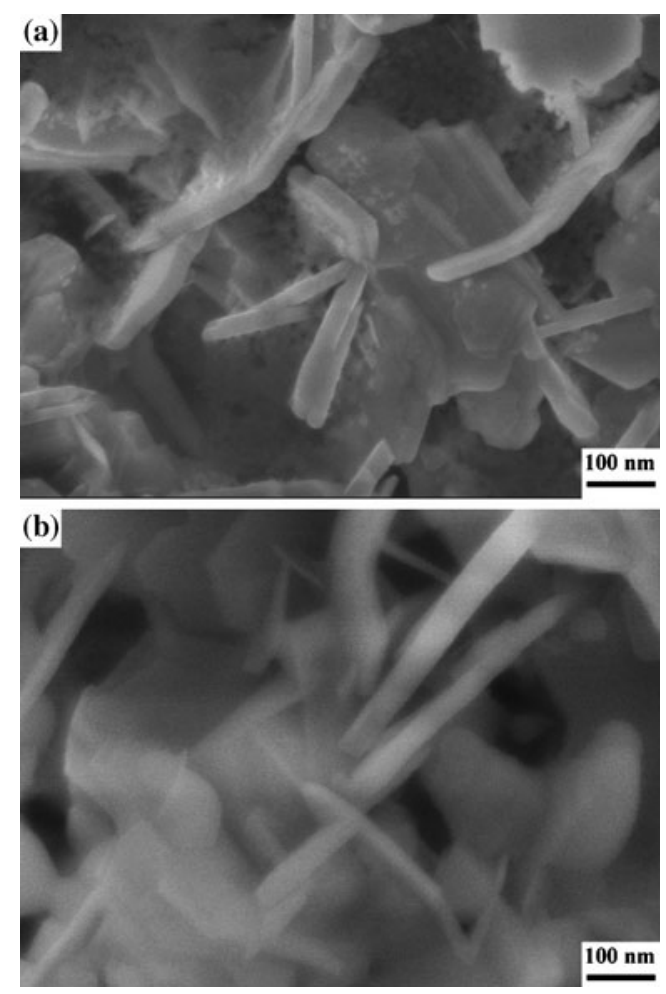

Figure 5. SEM micrographs of $\mathrm{SrAl}_{4} \mathrm{Fe}_{8} \mathrm{O}_{19}$ powder synthesized by citric-combustion method. The powders were calcined at $1000^{\circ} \mathrm{C}$ for (a) $3 \mathrm{~h}$ and (b) $5 \mathrm{~h}$.

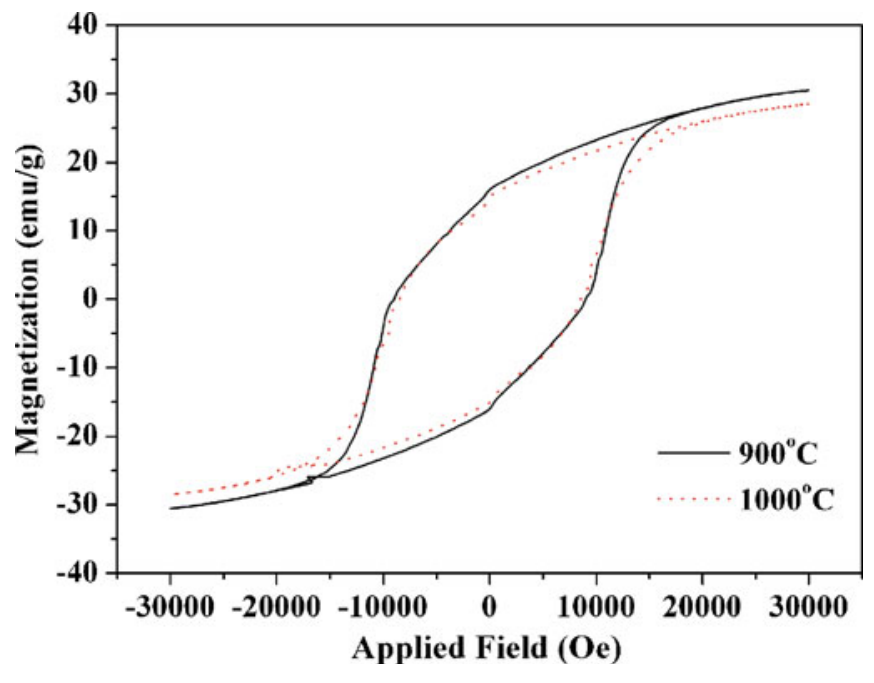

Figure 6. Room temperature hysteresis loops of $\mathrm{SrAl}_{4} \mathrm{Fe}_{8} \mathrm{O}_{19}$ powder synthesized by co-precipitation method.

zation of the powders calcined for $3 \mathrm{~h}$ and $5 \mathrm{~h}$ were 23.90 $\mathrm{emu} \cdot \mathrm{g}^{-1}$ and $23 \cdot 16 \mathrm{emu} \cdot \mathrm{g}^{-1}$, and the coercivity was $2 \cdot 19 \pm$ $0.04 \mathrm{kOe}$ and $0.45 \pm 0.04 \mathrm{kOe}$, respectively for the powders calcined for $3 \mathrm{~h}$ and $5 \mathrm{~h}$. As with the results for the co-precipitation method, these results were likely due to preferred growth in the $c$-axis for the magnetization (figure 5) 


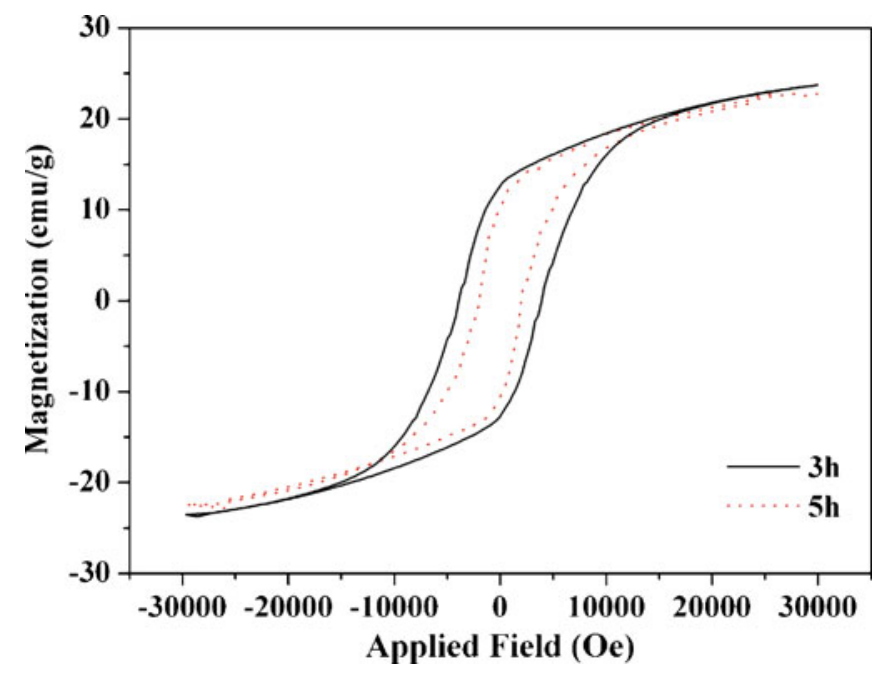

Figure 7. Room temperature hysteresis loops of $\mathrm{SrAl}_{4} \mathrm{Fe}_{8} \mathrm{O}_{19}$ powder synthesized by citric-combustion method.

and average grain size and anisotropy for the coercivity (table 1).

With increasing rate of Al-substitution, the saturation magnetization of $M$-type ferrite increases while the coercivity decreases. In view of this, the saturation magnetization and the coercivity of the $\mathrm{BaAl}_{4} \mathrm{Fe}_{8} \mathrm{O}_{19}$ powders synthesized by the coprecipitation were respectively larger than and close to $30.2 \mathrm{emu} \cdot \mathrm{g}^{-1}$ and $8.7 \mathrm{kOe}$ of $\mathrm{BaFe}_{10} \mathrm{Al}_{2} \mathrm{O}_{19}$ observed under an applied field of $15 \mathrm{kOe}$ as reported by Choi et al (2003). The saturation magnetization and the coercivity of the powders synthesized by the citric-combustion method might be respectively close to and smaller than the value reported by Choi et al (2003).

Comparing the two methods of synthesis, the magnetizations and coercivities of the powders synthesized by citriccombustion were smaller than those of the powders synthesized by coprecipitation. The first could be due to the smaller single-domain grain size in the powders synthesized by citric-combustion method (figure 5), and the second could be attributed to the nonuniform morphology of the powders consisting of the grains larger and smaller than the singledomain size; there seemed to be no obvious dependence in anisotropy.

Figures 8 and 9 show the variation in reflection loss of the powders vs frequency. The ferromagnetic resonance frequency $\left(f_{\mathrm{r}}\right)$ of ferrite can be given by following relation:

$$
2 \pi f_{\mathrm{r}}=\gamma \sqrt{H_{\theta} H_{\phi}} \text {. }
$$

This equation states that the ferromagnetic resonance frequency is related to the magnetocrystalline anisotropy fields $H_{\theta}$ and $H_{\phi}$ of ferrites. All samples showed two ferromagnetic resonance peaks in the range of $10-20 \mathrm{GHz}$, corresponding to the domain wall motion at the lower frequency and spin resonance at the higher frequency. The bandwidth of reso-

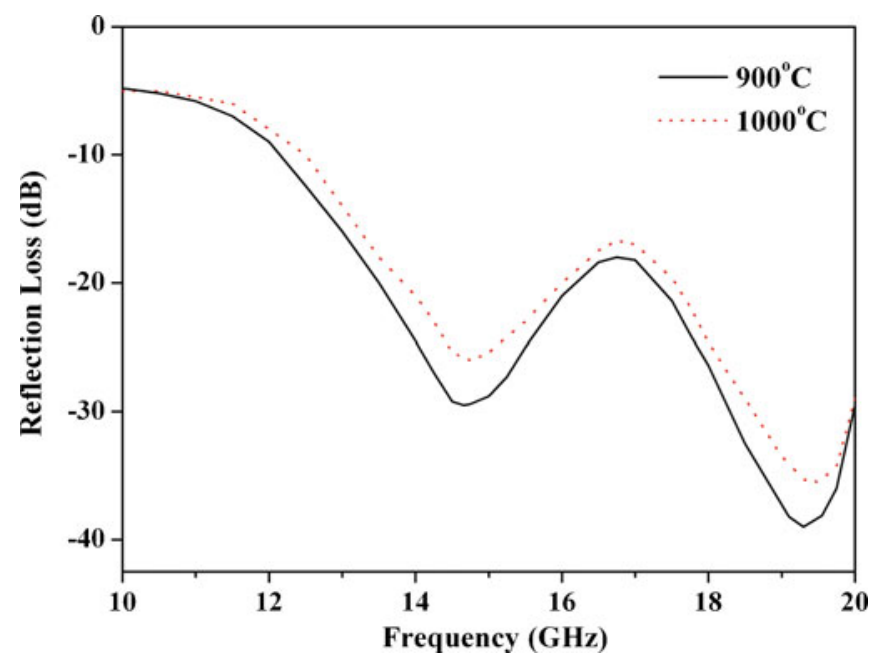

Figure 8. Variation of reflection loss of $\mathrm{SrAl}_{4} \mathrm{Fe}_{8} \mathrm{O}_{19}$ powder synthesized by co-precipitation method vs frequency.

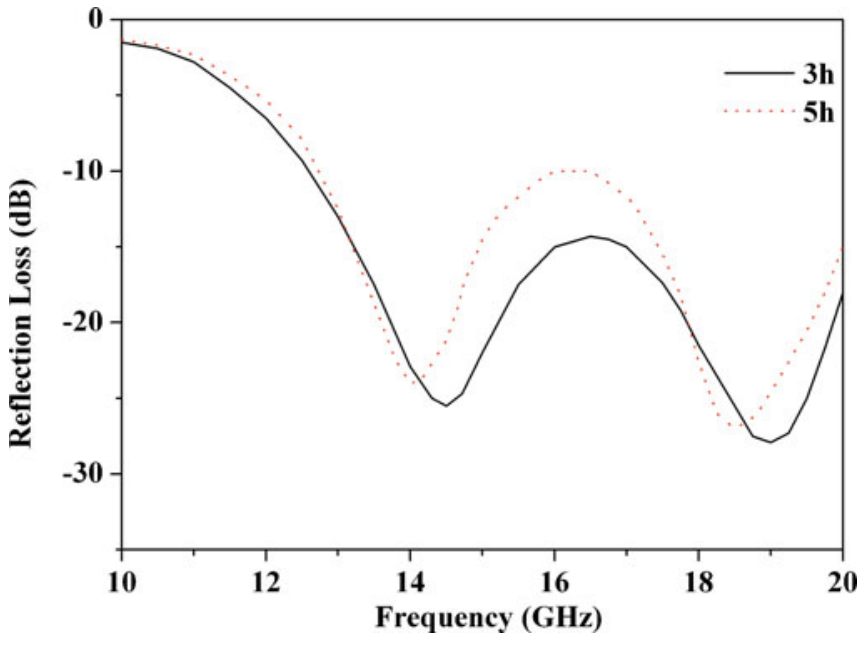

Figure 9. Variation of reflection loss of $\mathrm{SrAl}_{4} \mathrm{Fe}_{8} \mathrm{O}_{19}$ powder synthesized by citric-combustion method vs frequency.

nance frequency was defined as the frequency width in which the reflection loss was more than $-20 \mathrm{~dB}$. The resonance frequency, minimum reflection loss, and bandwidth of the powders are summarized in table 2. By comparison, the powders synthesized by the coprecipition method have higher resonance frequencies, larger reflection loss, and wider bandwidths. This could be attributed to their uniform grain morphology and small grain size close to the single-domain. The powder synthesized by the coprecipitation method at a calcining temperature of $900^{\circ} \mathrm{C}$ had the largest reflection loss value of $-39.0 \mathrm{~dB}$ and widest bandwidth of $4.4 \mathrm{GHz}$ at the higher matching resonance frequency of $19.30 \mathrm{GHz}$, and thus demonstrated the best microwave-absorbing properties. 
Table 2. Resonance frequency $\left(f_{\mathrm{r}}\right)$, minimum reflection loss $\left(R L_{\mathrm{min}}\right)$ and bandwidth $\left(R L_{\min }<-20 \mathrm{~dB}\right)$ of $\mathrm{SrAl}_{4} \mathrm{Fe}_{8} \mathrm{O}_{19}$ powders.

\begin{tabular}{|c|c|c|c|}
\hline Sample & $f_{\mathrm{r}}(\mathrm{GHz})$ & $R L_{\min }(\mathrm{dB})$ & Bandwidth (GHz) \\
\hline \multicolumn{4}{|c|}{ Coprecipitation method } \\
\hline \multirow[t]{2}{*}{$900^{\circ} \mathrm{C}$} & 14.66 & $-29 \cdot 5$ & $2 \cdot 8$ \\
\hline & $19 \cdot 30$ & $-39 \cdot 0$ & $4 \cdot 4$ \\
\hline \multirow[t]{2}{*}{$1000^{\circ} \mathrm{C}$} & $14 \cdot 75$ & $-26 \cdot 0$ & $2 \cdot 1$ \\
\hline & $19 \cdot 51$ & $-35 \cdot 5$ & $4 \cdot 0$ \\
\hline \multicolumn{4}{|c|}{ Citric-combustion method } \\
\hline \multirow[t]{2}{*}{$3 \mathrm{~h}$} & 14.47 & $-14 \cdot 5$ & $1 \cdot 6$ \\
\hline & $19 \cdot 03$ & $-27 \cdot 9$ & 1.9 \\
\hline \multirow[t]{2}{*}{$5 \mathrm{~h}$} & $14 \cdot 05$ & $-24 \cdot 0$ & $2 \cdot 0$ \\
\hline & $18 \cdot 47$ & $-27 \cdot 1$ & $1 \cdot 8$ \\
\hline
\end{tabular}

Chen et al (2010) fabricated the pure and La-substituted Sr-ferrite $\mathrm{Sr}_{1-x} \mathrm{La}_{x} \mathrm{Fe}_{12} \mathrm{O}_{19}(x=0-0.5)$ powders by a sol-gel technique followed by an auto-combustion process. The minimum reflection loss of the powders was improved from -24 to $-41.7 \mathrm{~dB}$ with increasing substitution rate from $x=0$ to $x=0.15$, but the response frequency was only at $\sim 9.6 \mathrm{GHz}$. By comparison, our study indicated that the Al-substitution remarkably increased response frequency of the Sr-ferrite powders.

\section{Conclusions}

$M$-type $\mathrm{SrAl}_{4} \mathrm{Fe}_{8} \mathrm{O}_{19}$ powders were synthesized by the coprecipitation method and the citric-combustion method. The synthesis technique greatly affected the microstructure, the magnetic property, and the microwave absorptivity of the $\mathrm{SrAl}_{4} \mathrm{Fe}_{8} \mathrm{O}_{19}$ powders. Comparatively, calcining temperature and calcining time had little effect on these properties. The powders synthesized by the coprecipitation method had uniform grain morphology, smaller grains near the single-domain size, and smaller shape anisotropy, and exhibited larger magnetization, larger coercivity, and better microwave-absorptivity compared to the powders synthesized by citric-combustion method. The grain size was found to be an important factor in determining these properties of the powders. By selecting the appropriate synthesis technique, the $\mathrm{SrAl}_{4} \mathrm{Fe}_{8} \mathrm{O}_{19}$ powder can be an effective microwave absorber for over $14 \mathrm{GHz}$ with satisfactory reflection loss.

\section{Acknowledgements}

The authors thank Mr Z Miao, Northwest Institute for NonFerrous Metal Research, for his kind assistance in SEM measurement, Mr S Liu, Advanced Material Analysis and Test Centre, Xi'an University of Technology, for his kind assistance in magnetic property and microwave absorption ability measurements, and the financial assistance of the specific scientific research projects of Shaanxi Provincial Education Committee (09KJ348).

\section{References}

Chen N, Yang K and Gu M 2010 J. Alloys Compd. 490609

Choi D H, Lee S W, An S Y, Park S I, Shim I B and Kim C S 2003 IEEE Trans. Magn. 392884

Han M, Ou Y, Chen W and Deng L 2009 J. Alloys Compd. 474185

Heczko O, Gerber R and Šimša Z 2000 Thin Solid Films 358206

Komarneni S, D'Arrigo M C, Leonelli C, Pellacani G C and Katsuki H 1998 J. Am. Ceram. Soc. 813041

Kreisel J, Vincent H, Taeest F, Pate M and Ganne J P 2001 J. Magn. Magn. Mater. 22417

Pankov V 1997 Mater. Sci. Eng. A224 101

Sablea S N, Rewatkarb K G and Nanoti V M 2009 Mater. Sci. Eng. B168 156

Wang X, Li D, Lu L and Wang X 1996 J. Alloys Compd. 23745 